\title{
CONDITIONS SURROUNDING THE OUTBREAK OF YELLOW DWARF VIRUS IN AUTUMN/WINTER-SOWN CEREALS IN CANTERBURY DURING 2005
}

\author{
D.A.J. TEULON, C.M. TILL and R.F. van TOOR \\ Crop \& Food Research, Private Bag 4704, Christchurch 8140, New Zealand
}

Corresponding author: teulond@crop.cri.nz

\begin{abstract}
To understand the factors contributing to a severe outbreak of yellow dwarf virus (YDV) in autumn/winter-sown wheat in Canterbury in 2005, records of winged cereal-inhabiting yellow dwarf virus-transmitting aphids caught in the $7.5 \mathrm{~m}$ Lincoln suction trap, and the degree day accumulations of ambient temperatures at Lincoln (from 1982 to 2006), were examined as measures of virus infection resulting from primary and secondary aphid infestation, respectively. The results strongly suggest that infestation by winged aphids into cereal crops was higher than usual throughout winter in 2005. The unusually warm May to August (especially July and August) 2005 enabled a greater than usual aphid build-up (i.e. through increased development and reproduction) in the crop at this time, spreading YDV. The unusually high numbers of flying aphids trapped in late spring were the result of additional aphid build-up in cereal crops in September and October. The results emphasise the need to include measures of secondary aphid infestation and virus infection in future YDV forecasts.
\end{abstract}

\section{INTRODUCTION}

The aphid-transmitted yellow dwarf viruses (YDV), barley yellow dwarf virus and cereal yellow dwarf virus (Mayo \& D'Arcy 1999), are major causes of cereal crop loss in New Zealand (Stufkens \& Farrell 1987, 1988; Farrell \& Stufkens 1992; Teulon et al. 1999a). At least six YDV aphid vectors are present in New Zealand. The cereal aphid Rhopalosiphum padi, known as the bird cherry oat aphid elsewhere, is the most prevalent in autumn crops (Farrell \& Stufkens 1992; Wratten et al. 1995; Teulon et al. 1999a,b; Teulon et al. 2004).

Primary YDV infection occurs as a result of aphids flying into cereal crops from other insect and disease reservoirs such as grasses and forage cereals. Secondary infection results from aphids moving within crops and includes virus transmission by offspring of the initial invaders. The critical time for aphid/YDV control is the early plant growth stages, especially before tillering ( $<$ GS20). Insecticides applied after GS31 are considered to have little effect on yield loss (Thackray et al. 2005).

Aphids have distinct peaks of flight activity in spring and autumn in Canterbury (Lowe 1967; Farrell \& Stufkens 1989), which is the main cereal-growing region in New Zealand. Lowe (1967) recommended that winter wheat should be sown after 1 June each year to avoid infection by late autumn aphid flights, which often cease by the end of May. Farrell \& Stufkens (1992) concluded that the late sowing of cereal crops in Canterbury (after 15 May) contributed to low levels of YDV infection. For crops sown after mid-May, a single insecticide application after autumn aphid flights have ceased, but before late tillering, was considered to be the most effective protection against YDV (Stufkens \& Farrell 1987). YDV outbreaks as a result of primary aphid infestation and virus infection were associated with aphid flights continuing into late June in 1962, 1966, 1985, 1987, 1990, 1998 and 1999 (Lowe 1967; Farrell \& Stufkens 1992; Teulon et al. 
1999a, 2001b). Secondary aphid infestation was implicated in higher than normal virus incidence in 1998 and 2000 (Teulon et al. 1999a, 2001a).

Canterbury wheat farmers reported severe infestations of YDV in autumn-sown wheat in 2005. Retrospective examination of YDV incidence of individual crops including cultivar, locality, elevation, sowing date and insecticide use, failed to reveal any relationships between these factors and virus incidence, possibly due to poor past recollection by farmers of virus incidence, misdiagnosis of virus symptoms and/or small sample size ( $\mathrm{n}=41 \mathrm{crops}$; Teulon et al. 2007). The work presented in this paper examines possible causes of the 2005 YDV outbreak on a more generic scale with respect to virus infection resulting from primary and secondary aphid infestation in that year. In particular, records of winged cereal-inhabiting YDV-transmitting aphids caught in a $7.5 \mathrm{~m}$ Lincoln suction trap and degree day accumulations of ambient temperatures at Lincoln (from 1982 to 2006) were examined to investigate the causes of the 2005 outbreak.

\section{Wheat growth stages}

\section{METHODS}

Sowing information of 41 autumn/winter wheat crops from a range of localities and elevations in Canterbury was supplied by farmers. The Sirius Wheat Calculator (Crop \& Food Research 2007) was used to estimate the dates of emergence and of Zadok's growth stages (GS) 21 and 30.

\section{Aphid flights}

Aphid flights have been monitored in a $7.5 \mathrm{~m}$ high suction trap at Lincoln from 1981 to 2006. From this data set, numbers of cereal-inhabiting YDV-transmitting aphids (R. padi, R. maidis, R. insertum, Metopolophium dirhodum, Sitobion miscanthi and/or $S$. nr. fragariae) caught in May to August for these years were collated.

\section{Degree days}

The number of degree days (DD) per month, above the lower thresholds of $5.8^{\circ} \mathrm{C}$ for R.padi (Elliott \& Kieckhefer 1989), was established from May to August (inclusive) from 1982 to 2006 . The upper threshold of $25.1^{\circ} \mathrm{C}$ (Elliott \& Kieckhefer 1989) was not used in this calculation as this temperature was seldom reached in these months. Degree days were calculated from meteorological data at the Crop \& Food Research Meteorological Station at Lincoln using the 'Meteor Weather Analysis Programme'. Rhopalosiphum padi is the most important aphid vector of YDV in Canterbury (Farrell \& Stufkens 1989; Teulon et al. 1999a; Teulon et al. 2004). This species was also the main aphid trapped in the Lincoln suction trap in autumn, winter and spring in 2005 (see below).

\section{Wheat growth stages}

\section{RESULTS AND DISCUSSION}

The approximate dates for plant emergence and Zadok's growth stages (GS) 21 and 30 for autumn wheat crops sown from April to June 2005, at a range of localities and elevations in Canterbury, are listed in Table 1. The data show that crops were at the vulnerable stage of crop development (emergence to GS 30) from mid-April to midSeptember, although for most crops this period would have been from May to August. We therefore focused our examination of aphid flights and degree-day accumulation on the May to August period.

TABLE 1: Approximate dates for Zadok's growth stages (GS) for wheat crops sown in April, May and June 2005.

\begin{tabular}{lccc}
\hline Sown & Emergence & GS 21 & GS 30 \\
\hline April $(\mathrm{n}=17)$ & mid April-mid May & early June-late July & mid-late Aug \\
May $(\mathrm{n}=19)$ & mid May-mid June & mid July-mid Aug & mid Aug-mid Sept \\
June $(\mathrm{n}=5)$ & July & late Aug-mid Sept & early-mid Sept \\
\hline
\end{tabular}


Figure 1 shows the numbers of cereal-inhabiting virus-transmitting aphids trapped in the $7.5 \mathrm{~m}$ high Lincoln suction trap and the degree day accumulations (base temperature of $5.8^{\circ} \mathrm{C}$ ) at Lincoln from 1982 to 2006, for May, June, July and August. Figure 2 shows data from May to August with selective months combined, enabling a comparison of the degree of primary and secondary aphid infestation and virus infection in 2005 with other years. For clarity and space, aphid data presented in both graphs are combined monthly values (traps were emptied weekly) whereas some data presented below are weekly values. Years with significant YDV incidence are circled based on records from 1983 to 1991 and 1998 to 2003 (excluding 2001) (Farrell \& Stufkens 1992, Teulon et al. 2001a, 2001b; D.A.J. Teulon, unpubl. data). There were no measures of YDV incidence from 1992 to 1997, 2001, 2004 and 2006.
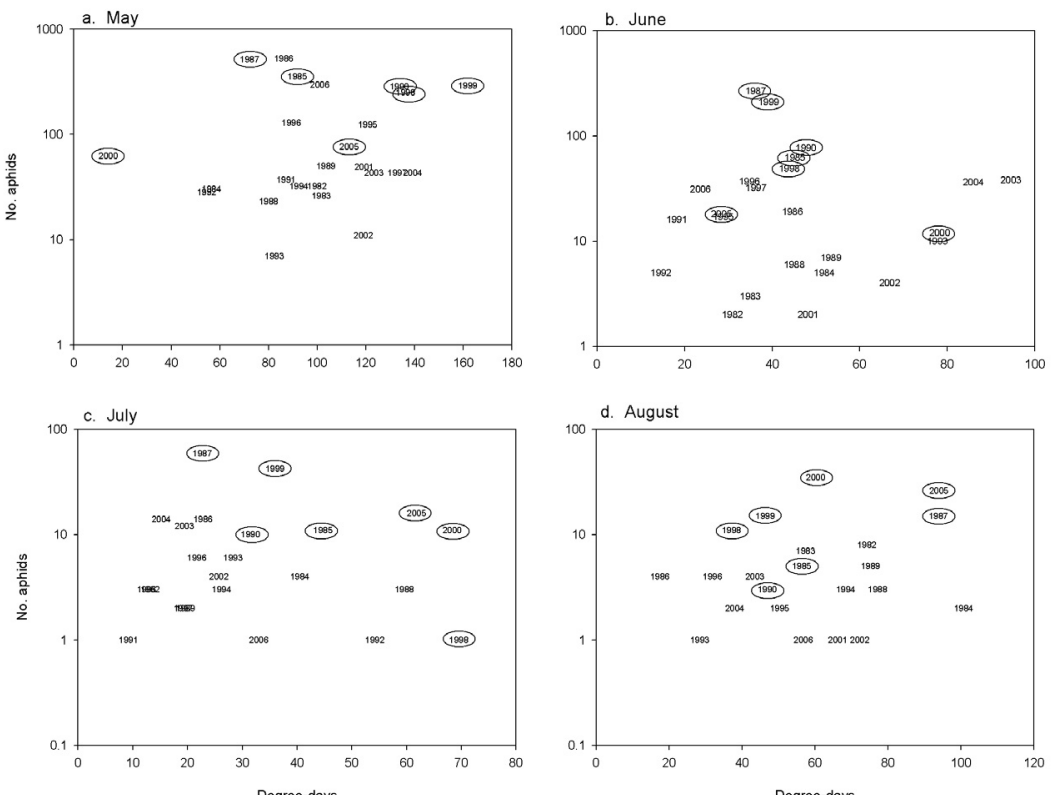

FIGURE 1: Numbers of aphids caught in a $7.5 \mathrm{~m}$ high suction trap at Lincoln (1982-2006) with respect to degree day accumulation for the same time period for the months of (a) May, (b) June, (c) July and (d) August. Circles denote years of significant YDV incidence. Vertical and horizontal lines denote the lowest degree days and aphid numbers, respectively, for years of high YDV incidence.

\section{Aphid flights - primary infestation}

The combined monthly capture for May and June 2005 was intermediate compared with other years (Figs 1a \& 1b). However, for July and August 2005 (Figs 1c \& 1d) the number of cereal-inhabiting virus-transmitting aphids trapped was relatively high compared to other years. With the exception of the years 1987 (74 aphids), 1999 (57 aphids) and 2000 (46 aphids), more aphids were trapped during July and August 2005 (42 aphids) than in any other years (Fig. 2d). The years 1987, 1999 and 2000 all had high levels of YDV (Farrell \& Stufkens 1992; Teulon et al. 2001a, 2001b). Additionally, in 
2005 aphids continued to be trapped continuously throughout the winter months (June to August) (3-8 aphids per week) whereas in most years ( $n=21 / 26$ years) (D.A.J. Teulon, unpubl. data) aphid flights virtually ceased (0-1 aphid per week for several weeks) at some stage over winter (see also Farrell \& Stufkens 1992, Teulon et al. 2004). The composition of the cereal-inhabiting YDV-transmitting aphids caught in autumn flights in 2005 at Lincoln was not unusual compared with other years (Farrell \& Stufkens 1992; Teulon et al. 2004). Most aphids (95\%) trapped were $R$. padi.

The peak number of aphids trapped in spring (300 aphids in early November 2005) and the total number of aphids trapped (934 aphids from September to December 2005) were very high in 2005 compared with historical records (D.A.J. Teulon, unpubl. data). Higher spring flights were only observed in the period from 1981 to 1985 (Farrell \& Stufkens 1988, D.A.J. Teulon, unpubl. data) before the introduction of the aphid parasitoid Aphidius rhopalosiphi (in 1985) for the control of Metopolophium dirhodum (Farrell \& Stufkens 1990).

\section{Degree days - secondary infestation}

The number of degree days (DD) above the developmental threshold of $5.8^{\circ} \mathrm{C}$ was slightly below average for April 2005, slightly above average for May, below average for June, but above average for July and August. Based on this measurement, July 2005 (61.8 DD) was the third warmest since 1980 (the warmest being 1998 and 2000, with 69.5 and 68.3 DD respectively) (Fig. 1c). August 2005 (93.9 DD) was the second warmest since 1980 (the warmest was in 1984 with 100.7 DD) (Fig. 1d). However, 2005 combined data gave the warmest July-August period since 1980 (Fig. 2d).

Other years with relatively warm winter months included 1984 and 1988, but these years had relatively low aphid flights especially in July and August (Figs 2 c \& d). Year 2000 was similar to 2005 in terms of combined degree days for June, July and August (206.7 cf. 184.1, respectively) (Fig. 2c) although June 2000 was much warmer (78.2 DD) than June 2005 (28.4 DD) (Fig. 1b) and August 2000 (60.2 DD) was colder than August 2005 (93.9 DD) (Fig. 1d). May 2000 (14.1 DD) was also colder than May 2005 (113.1 DD) (Fig. 1a). Year 2000 was also very similar to 2005 in terms of total aphid numbers trapped in June, July and August (50 cf. 61, respectively, Fig. 2c) and in July and August (34 cf. 44, respectively, Fig. 2d). Severe localised YDV was reported in winter wheat in the 2000 season (Teulon et al. 2001a).

\section{Summary of the 2005 conditions}

There were three distinguishing features of the 2005 Canterbury growing season compared with previous years:

(1) Degree day accumulations above a threshold for $R$. padi development for May to August combined (especially July and August combined) were the highest recorded.

(2) Flights of cereal-inhabiting virus-transmitting aphids continued through the winter months (June, July and August) at low levels. However, these low levels were much higher than historical levels, especially for July and August when aphid flights often cease.

(3) Flights of cereal-inhabiting virus-transmitting aphids were unusually high in late spring (especially November).

A reasonable interpretation of these data is:

(1) Infestation by winged aphids into cereal crops was higher than usual throughout winter in 2005 .

(2) The unusually warm winter enabled a greater than usual aphid build-up (i.e.through increased development and reproduction) in the crop at this time, spreading YDV.

(3) The unusually high numbers of flying aphids trapped in late spring reflected the earlier aphid build-up in cereal crops in September and October. 

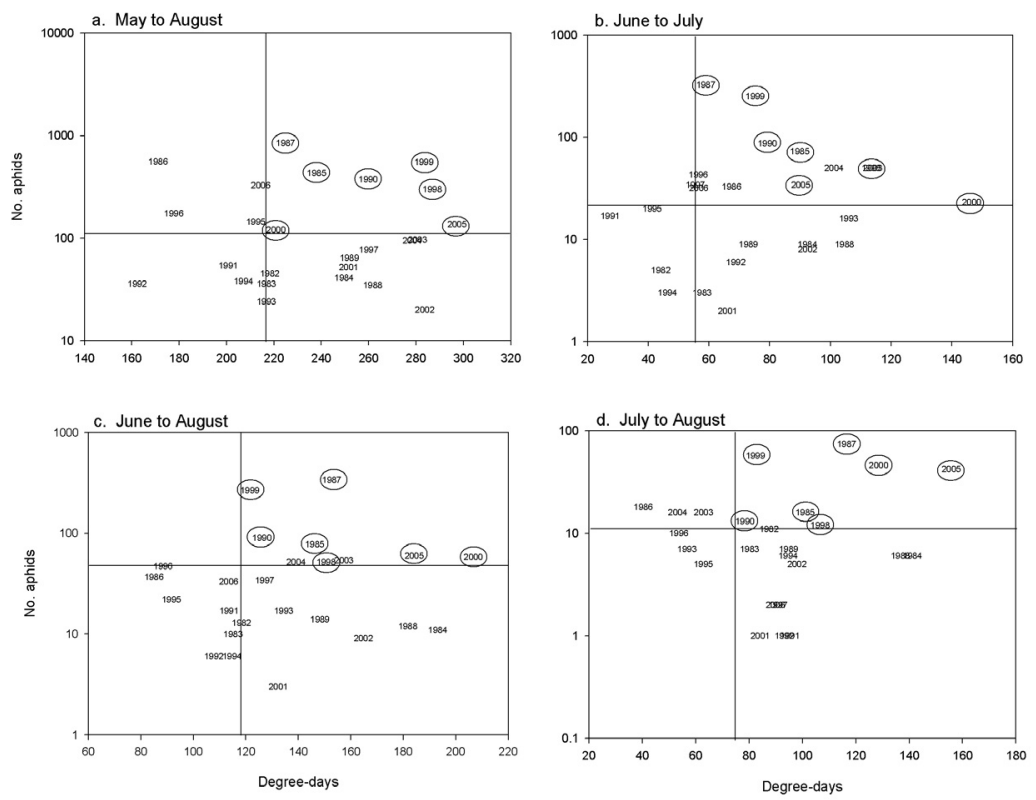

FIGURE 2: Numbers of aphids caught in a $7.5 \mathrm{~m}$ high suction trap at Lincoln (1982-2006) with respect to degree day accumulation for the same time period for (a) May to August, (b) July and July, (c) June to August and (d) July to August. Circles denote years of significant YDV incidence. Vertical and horizontal lines denote the lowest degree days and aphid numbers, respectively, for years of high YDV incidence.

\section{Forecasting YDV incidence}

Years with high records of YDV incidence group well together in the upper right hand of graphs combining total degree-day accumulation and aphid flight data for the months of May to August and especially June, July and August (Figs 2c \& 2d). The data indicate that years of high YDV incidence were associated with high autumn/winter aphid flights or moderate autumn/winter aphid flights and relatively warm autumn/winter months. The years 2003 and 2004 are also grouped with some of these graphs (Figs 2b \& 2c). Severe YDV was found in some crops in 2003 but overall YDV incidence in that year was low. No records of YDV incidence were taken in 2004. Changing insecticide use may account for the overall low YDV incidence in 2003 because in that year about $60 \%$ of crops were treated with imidacloprid, which was a significant increase over previous years (Teulon et al. 2007). Previous attempts to forecast YDV incidence in New Zealand have relied mostly on a measurement of aphid flight extent and timing (Farrell \& Stufkens 1992; Teulon et al. 1999a, see also AphidWatch.com). However, Teulon et al. (1999a) noted that a mild winter in 1998 may have accounted for greater than expected YDV incidence in that year and recommended that a measure of secondary aphid infestation and virus incidence may need to be included in future YDV forecasts. Teulon et al. (2001a) also implicated the warm winter of 2000 for localised severe incidence of YDV in that year. Additional (in-depth) analysis of the data set presented here and other factors contributing to YDV incidence, such as sowing date, insecticide use and the proportion of aphids 
carrying the virus into the crop, are likely to be informative in understanding the factors leading to YDV incidence in Canterbury autumn/winter sown wheat crops.

\section{ACKNOWLEDGEMENTS}

We thank all the farmers who freely supplied their management practices and recollections of virus conditions in 2005, and Ruth Butler (Crop \& Food Research) for statistical advice. This research was funded by the Foundation for Arable Research and The New Zealand Foundation for Science, Research and Technology.

\section{REFERENCES}

Elliott NC, Kieckhefer RW 1989. Effects of constant and fluctuating temperatures on immature development and age-specific life tables of Rhopalosiphum padi (L.) (Homoptera: Aphididae). Canadian Entomologist 121(2): 131-140.

Farrell JA, Stufkens MAW 1988. Abundance of the rose-grain aphid, Metopolophium dirhodum, on barley in Canterbury, New Zealand, 1984-87. New Zealand Journal of Zoology 15(4): 499-505.

Farrell JA, Stufkens MAW 1989. Flight activity and cereal host relationships of Rhopalosiphum spp. in Canterbury. New Zealand Journal of Crop and Horticultural Science 17: 1-7.

Farrell JA, Stufkens MAW 1990. The impact of Aphidius rhopalosiphi (Hymenoptera: Aphidiidae) on populations of the rose grain aphid (Metopolophium dirhodum) (Hemiptera, Aphididae) on cereals in Canterbury, New Zealand. Bulletin of Entomological Research 80: 377-383.

Farrell JA, Stufkens MAW 1992. Cereal aphid flights and barley yellow dwarf virus infection of cereals in Canterbury, New Zealand. New Zealand Journal of Crop and Horticultural Science 20: 407-412.

Lowe AD 1967. Sowing date as an aphid-virus control technique. Proceedings of the 20th New Zealand Weed and Pest Control Conference. Pp. 214-216.

Mayo MA, D’Arcy CJ 1999. Family Luteoviridae: a reclassification of Luteoviruses. In: Smith HC, Barker H ed. The Luteoviridae. CABI Publishing, Wallingford, UK. Pp. 15-22.

Stufkens MAW, Farrell JA 1987. Control of barley yellow dwarf virus (BYDV) disease of barley in mid-Canterbury. Proceedings of the 40th New Zealand Weed \& Pest Control Conference. Pp. 167-171.

Stufkens MAW, Farrell JA 1988. Effects of cereal host, insecticide and locality on the incidence of barley yellow dwarf virus in the South Island. Proceedings of the 41 st New Zealand Weed and Pest Control Conference. Pp. 34-38.

Thackray DJ, Ward LT, Thomas-Carroll ML, Jones RAC 2005. Role of winter-active aphids spreading barley yellow dwarf virus in decreasing wheat yields in a Mediterranean-type environment. Australian Journal of Agricultural Research 56: 1089-1099.

Teulon DAJ, Stufkens MAW, Nicol D, Harcourt SJ 1999a. Forecasting barley yellow dwarf virus in autumn-sown cereals in 1998. Proceedings of the 52nd New Zealand Plant Protection Conference. Pp. 187-191.

Teulon DAJ, Nicol D, Stufkens MAW 1999b. Apple grass aphid (Rhopalosiphum insertum) on cereals in Canterbury. Proceedings of the 52nd New Zealand Plant Protection Conference. Pp. 192-198.

Teulon DAJ, Fletcher JD, Cromey MG 2001a. Localised severe incidence of barley yellow dwarf virus in winter wheat. New Zealand Plant Protection 54: 253.

Teulon DAJ, Stufkens MAW, Coup DJ 2001b. Barley yellow dwarf virus forecast for autumn sown cereal crops 2000. Crop \& Food Research Confidential Report No. 364. Christchurch, New Zealand Institute for Crop \& Food Research Ltd. Used with permission from the Foundation for Arable Research. 
Teulon DAJ, Lankin GO, Stufkens MAW, Lee J, Travis G-R 2004. Local variation in cereal aphid flight activity in Canterbury. New Zealand Plant Protection 57: 221-226.

Teulon DAJ, Till C, van Toor R 2007. Conditions surrounding the 2005 outbreak of barley yellow dwarf virus in autumn/winter-sown cereals. Crop \& Food Research Confidential Report No. 1945. Christchurch, New Zealand Institute for Crop \& Food Research Ltd. Used with permission from the Foundation for Arable Research.

Wratten SD, Elliot NC, Farrell JA 1995. Integrated pest management in wheat. In: Dent D ed. Integrated Pest Management. Chapman \& Hall, London. Pp. 241-279. 